\title{
A comparative study of carbon dioxide absorption capacity of seven urban forest plant species of Banda Aceh, Indonesia
}

\author{
MALAHAYATI DAUD ${ }^{1}$, BETTY MAULIYA BUSTAM ${ }^{2, \boldsymbol{v}}$, BASTIAN ARIFIN $^{3}$ \\ 'Biology Graduate Program, Faculty of Mathematics and Natural Sciences, Universitas Syiah Kuala. Jl. Tgk Chik Pante Kulu No. 5, Kopelma \\ Darussalam, Syiah Kuala, Banda Aceh 23111, Aceh, Indonesia \\ ${ }^{2}$ Department of Biology, Faculty of Mathematics and Natural Sciences, Universitas Syiah Kuala. Jl. Tgk Chik Pante Kulu No. 5, Kopelma Darussalam, \\ Syiah Kuala, Banda Aceh 23111, Aceh, Indonesia. Tel.: +62-651-8012505, `email: bmbustam@unsyiah.ac.id \\ ${ }^{3}$ Department of Chemical Engineering, Faculty of Engineering, Universitas Syiah Kuala. Jl. Syekh Abdurauf As Sinkili No.7, Kopelma Darussalam \\ Banda Aceh 23111, Indonesia
}

Manuscript received: 9 May 2019. Revision accepted: 29 October 2019.

\begin{abstract}
Daud M, Bustam BM, Arifin B. 2019. A comparative study of carbon dioxide absorption capacity of seven urban forest plant species of Banda Aceh, Indonesia. Biodiversitas 20: 3372-3379. Global warming has been a major issue affecting all parts of the world in recent years. One method of reducing the impact of global warming is through supporting the green open space. The city government of Banda Aceh has targetted as much as $30 \%$ of its area to the formation of green open space. The BNI urban forest is one example of the green open spaces in the Banda Aceh city. This research was conducted to know the carbon dioxide absorption capacity in seven selected tree species found in the urban forest. The methods that has been applied was the explorative survey method with purposive sampling. The data was analyzed using linear regression and correlation analysis. The results showed that the highest ability of carbon dioxide absorption per leaf per hour was found in the Terminalia catappa $(0.511 \mathrm{~g} / \mathrm{leaf} / \mathrm{hour})$ and the lowest was found in the Calophyllum inophyllum (0.056 g/leaf/hour). While the highest carbon dioxide absorption per tree per hour was found in Pterocarpus indicus $(4,642,293 \mathrm{~g} /$ tree/hour) and the lowest was found in Calophyllum inophyllum $(162,640 \mathrm{~g} /$ tree/hour). The results of linear regression analysis showed that there was no strong correlation and no significant effect between leaf surface area and mass of carbohydrate, to capacity of carbon dioxide absorption in urban forest plants.
\end{abstract}

Keywords: Carbon dioxide absorption, leaf surface area, mass of carbohydrate, plant, urban forest

\section{INTRODUCTION}

Global warming, characterized by the rising earth temperatures associated directly with increasing greenhouse gases, is one of the major issues in the world today. Carbon dioxide $\left(\mathrm{CO}_{2}\right)$ is a major contributor to global warming, in addition to methane $\left(\mathrm{CH}_{4}\right)$, nitrous oxide $\left(\mathrm{N}_{2} \mathrm{O}\right)$, hydrofluorocarbons (HFC), perfluorocarbons (PFC) and sulfur hexafluoride $\left(\mathrm{SF}_{6}\right)$. The accumulation of these gases causes the earth's temperature to increase, triggering the occurrence of climate change (Cahyaningrum et al. 2014; Lugina et al. 2011; Ziska and Dukes 2011).

$\mathrm{CO}_{2}$ gas is the largest contributor of greenhouse gases (GHGs) compared to other gases (Purba and Khairunisa 2012; McPherson and Simpson 1999). Increased $\mathrm{CO}_{2}$ changes the natural balance of the carbon cycle, which acts to influence climatic conditions (Carvajal 2016). In Indonesia, the phenomenon that can be observed directly is the occurrence of changes in the rainy and dry seasons (Purba and Khairunisa 2012).

One way of reducing GHG concentrations in the atmosphere is by reducing the release of $\mathrm{CO}_{2}$ into the air. The impact of global warming may be reduced by replantation on degraded lands or development of green open space (GOS) in big cities by creating urban forests, parks, or other tree plantations (Lailati 2013). Urban green areas including urban forests can play important role in mitigating the impact of climate change by acting as urban carbon sinks by storing carbon in the form of above and below-ground biomass through photosynthesis (Nowak et al. 2013). The natural process that governs the carbon cycle maintains a balance between carbon sequestration and release back to the atmosphere (USGS 2008). Urban forests can reduce $\mathrm{CO}_{2}$ in the atmosphere in two ways. As the plant grows actively, the rate of $\mathrm{CO}_{2}$ uptake through photosynthesis is greater than its release through respiration, and the net result is a reduction of $\mathrm{CO}_{2}$ in the atmosphere. Urban forests can also be an important storage site for $\mathrm{CO}_{2}$. Trees around buildings can reduce heat and need for air conditioning (McPherson and Simpson 1999).

The species of plants to be grown in urban forests need to be selected carefully to maximize their function as absorbers of carbon dioxide $\left(\mathrm{CO}_{2}\right)$. Therefore, evaluation of the carbon dioxide absorption ability of the urban forest plant species is essential. The current study was, therefore, undertaken with the objective of investigating the carbon dioxide absorption ability of seven species of plants found in the urban forests of Banda Aceh, Indonesia. 


\section{MATERIALS AND METHODS}

\section{Study area}

The study site was BNI Urban Forest, Tibang Village, Banda Aceh, Indonesia (Figure 1). Seven species of dominant trees growing in the study area were selected to study their carbon dioxide absorption ability and the list of these species is provided as Table 1. This research was conducted from March to December 2017. Scientific analysis was carried out at the Weed Laboratory of Agrotechnology, Department of Agriculture Faculty of Syiah Kuala University, Banda Aceh, Indonesia and Herbarium and Basic Biology Laboratory of Department of Biology and Instrumental Laboratory of Chemistry Department of Mathematics Faculty, Syiah Kuala University, Banda Aceh, Indonesia.

\section{Procedures}

This research used the explorative survey method with purposive sampling. The plant samples were selected based on criteria such as their dominance in the BNI Urban Forest, their common use for avenue afforestation and plants which were rarely used for reforestation in other green spaces. Leaf samples were collected from the selected plant species, either by hand (if reachable) or using a pole. Samples were collected three times from three different individual trees of each plant species during two different time periods, i.e. before and after sunrise (between 06.0007.00 am and 11.00-12.00 am) on the same day, followed the method carried out by Dahlan 2008. Leaf samples were put into plastic bags, then soaked with $70 \%$ alcohol, shaken, allowed to stand for 15 minutes, then air-dried. Soaking in alcohol is done to prevent photosynthesis and continued respiration after the leaves are picked.

Determination of $\mathrm{CO}_{2}$ absorption per tree requires data on the number of leaves per tree. Following are the steps to determine the number of leaves per tree: (i) Count the number of branches in a tree, (ii) Group the branches according to their size, (iii) Select a branch as a sample and count the number of leaves, (iv) Multiply the number of leaves in the sample by the number of sample groups of branches, (v) Add up the product times so that the total number of leaves per tree is obtained (Ardiansyah 2009).

Leaf area measurement using Leaf Area Meter (Ardiansyah 2009) model G-5 made by Tokyo Photoelectric Co. Ltd. Carbon dioxide mass measurements were carried out using the carbohydrate method, whereas the measurement of reducing sugars was according to Nelson-Somogyi method (Sadasivam and Manickam 2005). Carbohydrate data obtained from the carbohydrate method were converted into carbon dioxide mass based on the photosynthetic reaction equation.

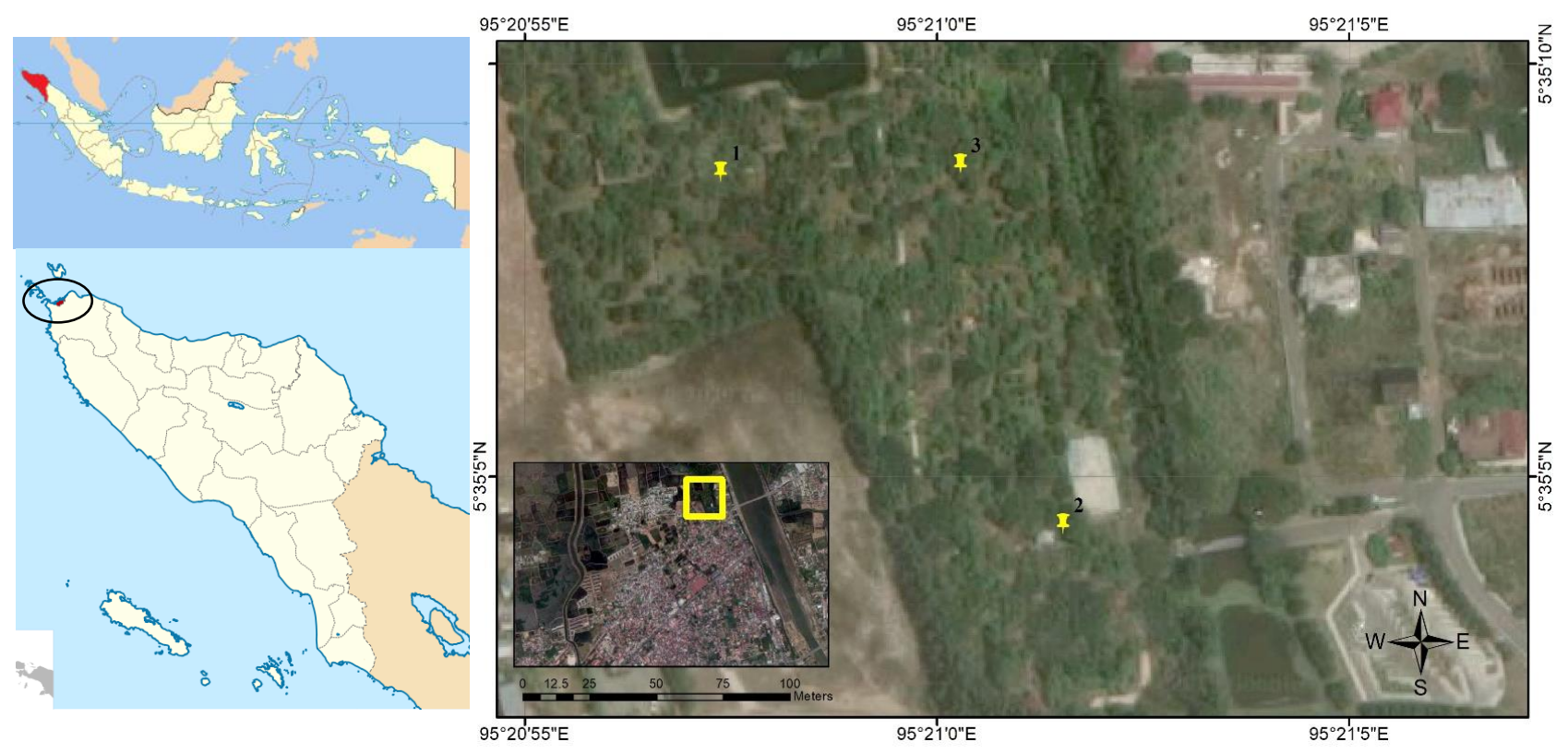

Figure 1. Location and point of the sample collection sites (yellow marks) in the BNI Urban Forest, Tibang, Banda Aceh, Indonesia

Table 1. List of plant species studied with their local names and botanical family

\begin{tabular}{lll}
\hline Species name & Local name & Family \\
\hline Barringtonia asiatica (L.) Kurz & Barrington, keben & Lecythidaceae \\
Calophyllum inophyllum L. & Nyamplung & Calophyllaceae \\
Filicium depiciens (Wight \& Arn.) Thwaites & Kerai payung & Sapindaceae \\
Mimusops elengi L. & Tanjung & Sapotaceae \\
Pterocarpus indicus Willd & Angsana & Fabaceae \\
Swietenia mahagoni (L.) Jacq. & Mahoni & Meliaceae \\
Terminalia catappa L. & Ketapang & Combretaceae \\
\hline
\end{tabular}


Leaf area per tree was calculated using the formula: (Average area of leaves per 30 grams of leaf wet weight $\times \sum$ leaves per tree) / $(\Sigma$ leaves per 30 grams of leaf wet weight).

Carbohydrate mass in fresh (wet) leaves is calculated by: Mass $\mathrm{C}_{6} \mathrm{H}_{12} \mathrm{O}_{6}=\%$ wet carbohydrate $\times$ leaf wet weight (30 grams)

Where is \% of wet carbohydrate: $(100 \%-\%$ moisture content) $/ 100 \times \%$ of dry carbohydrate

The moisture content of each leaf type in $\%$, calculated by way of: (Wet leaf weight-Dry leaf weight) / (Wet leaf weight) $\times 100 \%$

Mass of carbon dioxide was calculated using the formula: Mass $\mathrm{C}_{6} \mathrm{H}_{12} \mathrm{O}_{6} \times 1.47$

Carbohydrates (glucose equivalents) obtained from the carbohydrate method are converted to the mass of carbon dioxide from a mole ratio after the reaction coefficient is equalized based on the photosynthetic reaction equation (Avogadro equation):

$$
6 \mathrm{CO}_{2}+6 \mathrm{H}_{2} \mathrm{O} \rightarrow \mathrm{C}_{6} \mathrm{H}_{12} \mathrm{O}_{6}+6 \mathrm{O}_{2}
$$

In this reaction 1 mole of glucose is equivalent to 6 moles of carbon dioxide. The calculation method is as follows: (i) Mole $\mathrm{C}_{6} \mathrm{H}_{12} \mathrm{O}_{6}=$ Mass $\mathrm{C}_{6} \mathrm{H}_{12} \mathrm{O}_{6}$ : relative molecular mass $\mathrm{C}_{6} \mathrm{H}_{12} \mathrm{O}_{6}$; (ii) Mass $\mathrm{CO}_{2}=6$ mol $\mathrm{C}_{6} \mathrm{H}_{12} \mathrm{O}_{6} \times$ relative molecular mass $\mathrm{CO}_{2}$

$$
\text { Mass } \mathrm{CO}_{2}=\text { Mass } \mathrm{C}_{6} \mathrm{H}_{12} \mathrm{O}_{6} \times 1.47
$$

Where:

Relative molecular mass $\mathrm{C}_{6} \mathrm{H}_{12} \mathrm{O}_{6}=180(\mathrm{Ar} \mathrm{C}=12 ; \mathrm{Ar}$ $\mathrm{H}=1 ; \operatorname{Ar} \mathrm{O}=16$ )

Relative molecular mass $\mathrm{CO}_{2}=44$

Determination of $\mathrm{CO}_{2}$ absorption per leaf sample area (D) using the formula: $\left(\mathrm{CO}_{2}\right.$ mass) / (Leaf area (from 30 grams of leaf sample))

Determination of net $\mathrm{CO}_{2}$ absorption per leaf area per hour (Dt) using the formula:

$\mathrm{Dt}=\mathrm{D} / \Delta \mathrm{t}$

Where:

Dt: net $\mathrm{CO}_{2}$ absorption per leaf area

D: $\mathrm{CO}_{2}$ absorption per leaf sample area

$\Delta \mathrm{t}$ : difference in sampling time which starts at 6:00 a.m. until 10:00 a.m

Determination of $\mathrm{CO}_{2}$ absorption per leaf per hour

$\mathrm{Dl}=\mathrm{Dt} \times$ area per leaf

Where:

Dl: net $\mathrm{CO}_{2}$ absorption per leaf blade per hour

Dt: net $\mathrm{CO}_{2}$ absorption per leaf area

Determination of $\mathrm{CO}_{2}$ absorption per tree per hour (Dn)

Dn $=$ Dt $\times \sum \mathrm{d} \times$ area per leaf
Where:

Dn: $\mathrm{CO}_{2}$ net absorption per tree per hour

Dt: net $\mathrm{CO}_{2}$ absorption per leaf area

$\sum \mathrm{d}$ : number of leaves per tree (Ardiansyah 2009)

Determination of $\mathrm{CO}_{2}$ absorption per tree per year (Dy)

Dy $=[\{$ Dn $\times t\}+\{$ Dn $\times(A-t) \times 0.46\}] \times 365$

Where:

Dy: net $\mathrm{CO}_{2}$ absorption per tree per year

Dn: $\mathrm{CO}_{2}$ net absorption per tree per hour

A: the average value of the maximum exposure time per day, unit in hours/day

$\mathrm{t}$ : the average value of the actual exposure time per day in Banda Aceh, units in hours/day

0,46: comparison between average rate of photosynthesis on cloudy day with sunny day (Sitompul and Guritno 1995)

365: number of days in a year (Gratimah 2009)

Relationship between carbohydrate mass and leaf surface area and their influence on carbon dioxide absorption per leaf and per tree was determined using linear regression analysis and test correlation (Lailati 2013).

\section{RESULTS AND DISCUSSION}

The mass of carbohydrates in the leaf samples of seven species of plants collected at $06.00 \mathrm{am}$ and $11.00 \mathrm{am}$, the difference between these carbohydrate masses and the mass of absorbed carbon dioxide calculated based on these values is provided in Table 2.

The highest carbohydrate mass in leaf samples collected at 06.00 am was $5.460 \mathrm{~g}$ found in $S$. mahagoni and the lowest was $2.260 \mathrm{~g}$ in P. Indicus (Table 2). The highest carbohydrate mass in the samples collected at $11.00 \mathrm{am}$ was also found in $S$. mahagoni $(6.420 \mathrm{~g})$ and the lowest was found in B. asiatica $(2.720 \mathrm{~g})$. Although $S$. mahagoni had the highest carbohydrate mass at both sampling times (at $06.00 \mathrm{am}$ and $11.00 \mathrm{am}$ ), it was not the species with high carbon dioxide absorption, either per leaf or per tree (Table 3 and Table 4). This is maybe because not all photosynthetic products are stored in the form of carbohydrates, as they are partially reused for other metabolic processes such as respiration.

Each type of plant has a different carbohydrate mass. All plants studied increased their carbohydrate mass from $06.00 \mathrm{am}$ to $11.00 \mathrm{am}$. At $06.00 \mathrm{am}$, there is no photosynthesis because the plants have not received enough intensity of sunlight. The intensity of sunlight during sampling at 06.00 am ranged from 130 lux to 370 lux. Photosynthesis cannot occur if one of the required factors (sunlight) does not exist. The function of light is to excite the specific chlorophyll molecules at the reaction center (Taiz and Zeiger 2003). At 11.00 am, the mass of carbohydrates present is greater because of the commencement of photosynthesis with the increased 
intensity of sunlight. The intensity of sunlight at $11.00 \mathrm{am}$ ranges from 30000 lux to 92100 lux. The results of this study were in line with that of Ardiansyah (2009), where carbohydrate mass increased from 05.00 am to $05.00 \mathrm{pm}$. Fitter and Hay (2001) stated that the intensity of sunlight always varies every day and depends on the season, so the wavelength received may vary. Sari et al. (2015) stated that the intensity of light rises and falls based on cloud conditions in the atmosphere. The intensity of sunlight stabilizes at an intensity exceeding 320000 lux at around $09.00 \mathrm{am}$. Heldt (2005) opines that during photosynthesis of green plants, light is collected primarily by chlorophyll, pigments that absorb light at wavelengths below $480 \mathrm{~nm}$, and between 550 and $700 \mathrm{~nm}$. Pigments are often named after viewing the absorbance maximum wavelength. The maximum absorption wavelength of chlorophyll a is $700 \mathrm{~nm}$.

Similar research on the ability of carbon dioxide uptake in different crops has been conducted by Sinambela (2006) who studied carbon uptake in 5 urban forest plant species from 5 families, namely Sapindaceae, Clusiaceae, Gnetaceae, Sapotaceae, and Fabaceae. Purwaningsih (2007) examined carbon uptake in 25 urban forest plant species in the Bogor botanical garden belonging to 8 families: Caesalpiniaceae, Sapindaceae, Sapotaceae, Papilionaceae, Mimosaceae, Meliaceae, Moraceae, and Annonaceae. Ardiansyah (2009) studied carbon uptake in 14 plant species belonging to 9 families: Pinaceae, Euphorbiaceae, Fabaceae, Clusiaceae, Dilleniaceae, Myrtaceae, Magnoliaceae, Bignoniaceae, and Verbenaceae. Lailati (2013) examined carbon uptake in 15 plant species of 13 families: Burseraceae, Hammamelidaceae, Dipterocarpaceae, Bombaceae, Moraceae, Santalaceae, Thymelaeaceae, Anacardiaceae, Sapotaceae, Apocynaceae, Euphorbiaceae, Annonaceae, and Combretaceae. The results of all these studies have also shown increased carbohydrate mass along with increasing sampling time.

Table 2. Species-wise mass of carbohydrate in leaf samples collected at $06.00 \mathrm{am}$ and $11.00 \mathrm{am}$, difference between mass of carbohydrates, and the mass of carbon dioxide absorbed

\begin{tabular}{lcccc}
\hline \multicolumn{1}{c}{ Species } & $\begin{array}{c}\text { Mass of } \\
\text { carbohydrate in leaf } \\
\text { sample collected at } \\
\mathbf{0 6 . 0 0} \mathbf{~ a m}(\mathbf{g})\end{array}$ & $\begin{array}{c}\text { Mass of } \\
\text { carbohydrate in leaf } \\
\text { sample collected at } \\
\mathbf{1 1 . 0 0} \text { am }(\mathbf{g})\end{array}$ & $\begin{array}{c}\text { Difference } \\
\text { between mass of } \\
\text { carbohydrates } \\
\text { (g) }\end{array}$ & $\begin{array}{c}\text { Mass of } \\
\text { carbon } \\
\text { dioxide (g) }\end{array}$ \\
\hline Barringtonia asiatica (L.) Kurz & 2.350 & 2.720 & 0.372 & 0.550 \\
Calophyllum inophyllum L. & 4.620 & 4.770 & 0.153 & 0.220 \\
Filicium depiciens (Wight\&Arn.) Thwaites & 4.110 & 4.310 & 0.196 & 0.290 \\
Mimusops elengi L. & 3.840 & 4.280 & 0.440 & 0.650 \\
Pterocarpus indicus Willd & 2.260 & 3.170 & 0.907 & 0.907 \\
Swietenia mahagoni (L.) Jacq. & 5.460 & 6.430 & 0.968 & 1.420 \\
Terminalia catappa L. & 2.830 & 4.220 & 1.390 & 2.050 \\
\hline
\end{tabular}

Table 3. Number of leaves per tree, average leaf surface area per leaf and total leaf surface area per tree

\begin{tabular}{lccc}
\hline Species & $\begin{array}{c}\text { Number of leaves per } \\
\text { tree }\end{array}$ & $\begin{array}{c}\text { average leaf surface area } \\
\text { per leaf }\left(\mathbf{c m}^{\mathbf{2}}\right)\end{array}$ & $\begin{array}{c}\text { leaf surface area per } \\
\text { tree }\left(\mathbf{c m}^{\mathbf{2}}\right)\end{array}$ \\
\hline Barringtonia asiatica (L.) Kurz & \pm 1788 & 515.80 & 461125.20 \\
Calophyllum inophyllum L. & \pm 3780 & 70.96 & 19159.20 \\
Filicium depiciens (Wight \& Arn.) Thwaites & \pm 2238 & 73.46 & 10274.75 \\
Mimusops elengi L. & \pm 8379 & 46.74 & 14503.95 \\
Pterocarpus indicus Willd & \pm 7292 & 329.74 & 300554.97 \\
Swietenia mahagoni (L.) Jacq. & \pm 1873 & 319.74 & 119773.98 \\
Terminalia catappa L. & \pm 3369 & 331.93 & 279565.24 \\
\hline
\end{tabular}

Table 4. Carbon dioxide absorption capacity per leaf

\begin{tabular}{lccc}
\hline Species & $\begin{array}{c}\text { Carbon dioxide } \\
\text { absorbtion per leaf } \\
\text { sample area }\left(\mathbf{g} / \mathbf{c m}^{2}\right)\end{array}$ & $\begin{array}{c}\text { Carbon dioxide absorbtion } \\
\text { per } \mathbf{c m}^{\mathbf{2}} \mathbf{l e a f} \text { area per hour } \\
\left(\mathbf{g} / \mathbf{c m}^{2} / \mathbf{h o u r}\right)\end{array}$ & $\begin{array}{c}\text { Carbon dioxide } \\
\text { absorbtion per leaf } \\
\text { per hour }(\mathbf{g} / \mathbf{l e a f} / \mathbf{h o u r})\end{array}$ \\
\hline Barringtonia asiatica (L.) Kurz & 0.0011 & 0.0003 & 0.137 \\
Calophyllum inophyllum L. & 0.0032 & 0.0008 & 0.056 \\
Filicium depiciens (Wight \& Arn.) Thwaites & 0.0039 & 0.0010 & 0.072 \\
Mimusops elengi L. & 0.0138 & 0.0035 & 0.162 \\
Pterocarpus indicus Willd & 0.0040 & 0.0010 & 0.333 \\
Swietenia mahagoni (L.) Jacq. & 0.0045 & 0.0011 & 0.356 \\
Terminalia catappa L. & 0.0062 & 0.0015 & 0.511 \\
\hline
\end{tabular}


In the seven species studied, there was a difference in carbohydrate mass (Table 2), indicating that each type of plant has its own ability to produce carbohydrates. The $T$. catappa had the maximum carbohydrate mass for five hours (at $06.00 \mathrm{am}-11.00 \mathrm{am}$ ), which is equal to $1,390 \mathrm{~g}$, so this is also the plant that absorbed the maximum $\mathrm{CO}_{2}$ for photosynthesis process which was equal to $2.050 \mathrm{~g}$. $C$. inophyllum absorbed the least $\mathrm{CO}_{2}$, which was equal to $0.220 \mathrm{~g}$. The more $\mathrm{CO}_{2}$ absorbed by plants, the more carbohydrates were formed. This is consistent with the statement of Purwaningsih (2007) and Lailati (2013), that the mass of carbon dioxide absorbed is directly proportional to the mass of carbohydrates because in the process of photosynthesis the amount of $\mathrm{C}$ in $\mathrm{CO}_{2}$ is directly proportional to the amount of $\mathrm{C}$ bound in sugar during photosynthesis.

\section{Carbon dioxide absorption per leaf}

Among the seven species of plants selected for study, four had simple leaf types (Figure 2) and three had compound leaf types (Figure 3).
Different plant species produce leaves that vary greatly in size and shape (Kerstetter and Poethig 1998; Perez-Perez et al. 2002) and leaf morphological features are often the results of a genetic program influenced by environmental influences. Almost all leaves are specialized for photosynthesis (Benfey 2017). Leman et al. (2017) stated that the leaf surface area plays an important role in absorbing $\mathrm{CO}_{2}$ than the fresh weight and dry weight of leaves.

In the category of simple leaves, leaves of $B$. asiatica showed maximum surface area per leaf with an average of $515.80 \mathrm{~cm}^{2}$. M. elengi had the smallest leaf surface area with an average of $46.74 \mathrm{~cm}^{2}$ per leaf. Among the compound leaf types, the largest leaf surface area was found in case of $P$. indicus with an average area of 329.74 $\mathrm{cm}^{2}$ per leaf. While the smallest surface area was found in F. decipiens leaf with an average of $73.46 \mathrm{~cm}^{2}$ (Table 3).

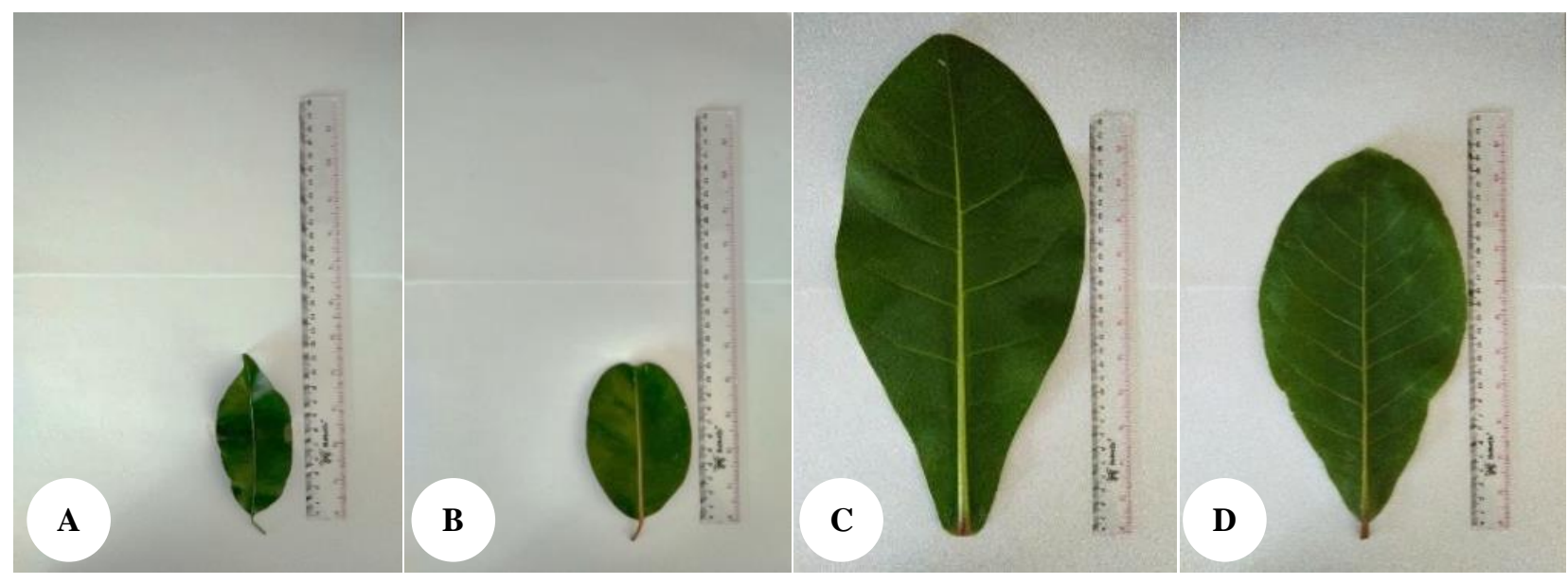

Figure 2. Species having simple leaves: (A) M. elengi (B) C. inophyllum (C) B. asiatica, and (D) T. catappa
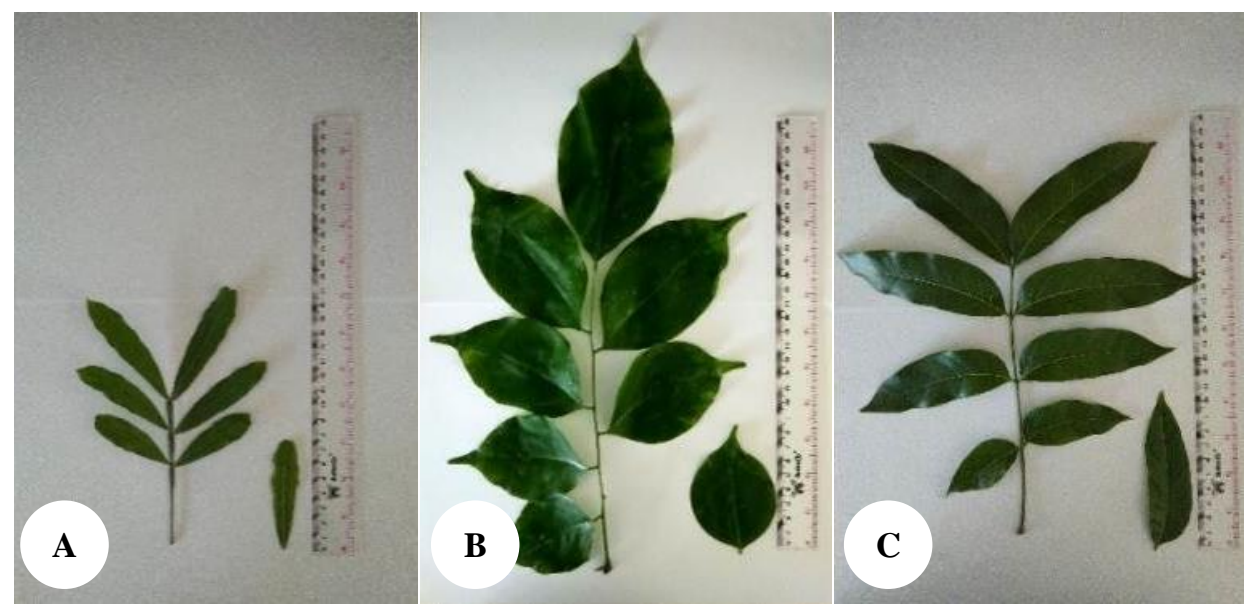

Figure 3. Species with compound leaves: (A) F. depiciens (B) P. indicus and (C) S. mahagoni 
Table 5. Carbon dioxide absorption per tree per hour, and per year

\begin{tabular}{lcc}
\hline Species & $\begin{array}{c}\text { Carbon dioxide absorbtion per tree } \\
\text { per hour (g/tree/hour) }\end{array}$ & $\begin{array}{c}\text { Carbon dioxide absorbtion per tree } \\
\text { per year } \mathbf{( k g / t r e e / h o u r )}\end{array}$ \\
\hline Barringtonia asiatica (L.) Kurz & 162.640 & $584,137.054$ \\
Calophyllum inophyllum L. & 146.173 & $524,994.749$ \\
Filicium depiciens (Wight \& Arn.) Thwaites & 241.084 & $865,878.767$ \\
Mimusops elengi L. & 878.516 & $3,155278.425$ \\
Pterocarpus indicus Willd & 4624.293 & $1,660,8610.879$ \\
Swietenia mahagoni (L.) Jacq. & 403.409 & $1,448,884.339$ \\
Terminalia catappa L. & 1792.653 & $6,438,494.301$ \\
\hline
\end{tabular}

Table 6. Regression analysis between mass of carbohydrate and leaf surface area, and the carbon dioxide absorption per leaf and per tree

\begin{tabular}{|c|c|c|c|c|}
\hline Correlation & Linear equation & $\begin{array}{c}\text { Coefficient of } \\
\text { Determination } \\
\left(\mathbf{R}^{2}\right)\end{array}$ & $\begin{array}{c}\text { Coefficient of } \\
\text { Correlation } \\
\text { (r) }\end{array}$ & Sig \\
\hline Mass of carbohydrate vs $\mathrm{CO}_{2}$ absorption per leaf & $\mathrm{y}=0.135+0.023 \mathrm{x}_{1}$ & $2.6 \%$ & 0.160 & 0.732 \\
\hline Leaf surface area vs $\mathrm{CO}_{2}$ absorption per leaf & $\mathrm{y}=0.122+0.0001 \mathrm{x}_{2}$ & $23.3 \%$ & 0.484 & 0.273 \\
\hline Mass of carbohydrate vs $\mathrm{CO}_{2}$ absorption per tree & $y=3.419 .845-0.525 x_{1}$ & $14.8 \%$ & 0.384 & 0.395 \\
\hline Leaf surface area vs $\mathrm{CO}_{2}$ absorption per tree & $\mathrm{y}=662.005+2.141 \mathrm{x}_{2}$ & $5.5 \%$ & 0.235 & 0.611 \\
\hline
\end{tabular}

The leaf surface area per tree represents the total area of canopy cover in a tree. The highest leaf area per tree was $461125.20 \mathrm{~cm}^{2}$ which was found in case of B. asiatica. $F$. decipiens had the lowest leaf area per tree which was $10274.75 \mathrm{~cm}^{2}$ (Table 3). The total leaf area of a tree was not always directly proportional to the area per leaf because the leaf area per tree is also influenced by the total number of leaves per tree. Even if the area per leaf of a plant is small, but if the number of leaves in the tree is more, then the total leaf area per tree will be large. This is consistent with Sinambela's (2006) statement, that the average leaf area is not always directly proportional to the leaf area per plant.

The carbon dioxide mass obtained does not determine the capacity to absorb carbon dioxide by a plant, because it is determined by the leaf area. The absorption capacity of carbon dioxide per leaf is shown in Table 4. The results showed that the plants that have the largest leaf area do not necessarily have a high absorption of carbon dioxide. Ardiansyah (2009) and Lailati (2013) stated that carbon dioxide absorption is highly dependent on the area of leaf samples tested because the area of leaf samples under study is a dividing factor in the calculation formula. The wider the leaf, the smaller will be the absorption capacity of carbon dioxide. Conversely, smaller the leaf area greater is the capacity to absorb carbon dioxide.

In this study, the plant that showed the highest carbon dioxide absorption capacity per $\mathrm{cm}^{2}$ leaf area per hour was $M$. elengi which absorbed $0.0035 \mathrm{~g} / \mathrm{cm}^{2} / \mathrm{hr}$ of carbon dioxide, and the lowest was $B$. asiatica with 0.0003 $\mathrm{g} / \mathrm{cm}^{2} / \mathrm{hr}$. This was because the leaves of $M$. elengi were the smallest $\left(46.74 \mathrm{~cm}^{2}\right)$, whereas those of $B$. asiatica were the largest $\left(515.80 \mathrm{~cm}^{2}\right)$ (Table 3). However, the highest carbon dioxide absorption per leaf per hour was found in $T$. catappa plants which absorbed $0.511 \mathrm{~g} / \mathrm{leaf} / \mathrm{hour}$, and the lowest was $C$. inophyllum with $0.056 \mathrm{~g} / \mathrm{leaf} / \mathrm{hour}$ (Table 4). This is because although the leaves of T. catappa were not the largest, it had the highest $\mathrm{CO}_{2}$ mass $(2.050 \mathrm{~g})$ compared to other plant species, whereas $C$. inophyllum had the lowest $\mathrm{CO}_{2}$ mass $(0.220 \mathrm{~g})$ (Table 2) and also small leaf area $\left(70.96 \mathrm{~cm}^{2}\right)$ (Table 3 ). $\mathrm{CO}_{2}$ mass is directly proportional to the mass of carbohydrates produced. This is in accordance with the finding by Purwaningsih (2007), if the mass of carbohydrates obtained is high then the mass of carbon dioxide in plants will be high, whereas low carbohydrate mass indicates low absorption.

The ability to absorb carbon dioxide in selected BNI Urban Forest plants vary among species. The ability to absorb carbon dioxide per tree depends on the total number of leaves on the tree. More the number of leaves, greater is the ability of the plant to absorb carbon dioxide from the air.

The absorption of carbon dioxide per tree and per year is shown in Table 5. This table shows that the highest absorption capacity of carbon dioxide per tree per hour was shown by $P$. indicus which absorbed as much as 4624.293 $\mathrm{g} /$ tree/hour of $\mathrm{CO}_{2}$ and the lowest was $C$. inophyllum with of $146.173 \mathrm{~g} /$ tree/hour. The absorption capacity of carbon dioxide per tree per year is proportional to the absorption rate of carbon dioxide per tree per hour. The highest absorption of carbon dioxide per tree per year was also found in $P$. indicus with $16,608,610.879 \mathrm{~kg} /$ tree/year and the lowest was $C$. inophyllum species of 524,994,749 $\mathrm{kg} /$ tree/year. These results are different from those reported by Sinambela (2006). According to Sinambela (2006), the net $\mathrm{CO}_{2}$ absorption per individual trees and per hectare of land was directly proportional to the net $\mathrm{CO}_{2}$ absorption per leaf area. In this study, the absorption of $\mathrm{CO}_{2}$ per leaf is directly proportional to the mass of carbohydrates formed and the net $\mathrm{CO}_{2}$ absorbed by the plant. Although $B$. asiatica has the largest leaf, the highest absorption capacity of carbon dioxide was found in $P$. indicus plant. The results of research conducted by Pane et al. 2016 and Misni et al. 
2015 also stated that $P$. indicus is one species that has a higher carbon absorption.

Although the $M$. elengi plant had the highest number of leaves $\left( \pm 8,379\right.$ leaves per tree), its $\mathrm{CO}_{2}$ absorption of capacity was low because this plant had the smallest leaf area compared to other plants. $P$. indicus had the second largest number of leaves after $M$. elengi, which was $\pm 7,292$ leaves (Table 3). The leaves of this species were of compound type, so the ability to absorb carbon dioxide was more than other species because each leaflet was able to absorb carbon dioxide for photosynthesis. This is in accordance with Lailati (2013) which stated that the larger the size of the leaf area, the greater the capacity to absorb carbon dioxide. Larcher (1980) in McPherson and Simpson (1999) stated during photosynthesis, atmospheric $\mathrm{CO}_{2}$ enters the leaf through the surface pores, joins with water and converted into cellulose sugars and other materials in chemical reactions catalyzed by sunlight. Most of these materials become wood although some are removed in the form of $\mathrm{CO}_{2}$ when plant respirated or used to form leaves that are eventually shed by trees. Birdsey (1992) in McPherson and Simpson (1999) adds that the distribution of $\mathrm{CO}_{2}$ stored for a forest tree is about $51 \%$ in stems, $30 \%$ in branches and twigs and 3\% in leaves. Approximately 18$24 \%$ of the total carbon stored in adult forest plants is at the root. The result of a study by MV Oviantari et al. (2018) showed that, besides trees, herbaceous plants also have a high $\mathrm{CO}_{2}$ uptake which is found in trumpet and ararea flower vegetation. The presence of trees in the urban green space is very important for providing ecosystem service, especially in reducing greenhouse gas emissions. However, carbon dioxide storage can be increased by increasing the number of forest plants in urban parks (Lee et al. 2014; Nowak et al. 2013)

The results obtained for each parameter studied were then analyzed statistically to see the relationship between each variable, namely $\mathrm{CO}_{2}$ absorption per leaf and per tree. The results of regression analysis and correlation test state that each variable has a different relationship with the absorption of carbon dioxide per leaf blade.

Carbohydrate mass has a very low relation to the absorption of $\mathrm{CO}_{2}$ per leaf $(\mathrm{r}=0.160)$. The surface area per leaves has a moderate relationship to the absorption of $\mathrm{CO}_{2}$ $(\mathrm{r}=0.484)$. There is no significant effect on $\mathrm{CO}_{2}$ absorption whether tested as single parameter or tested simultaneously (Table 6). Similarly, low levels of association with $\mathrm{CO}_{2}$ absorption per tree were found in carbohydrate mass $(\mathrm{r}=0.384)$. Leaf surface area also has a low relation and non-significant influence on absorption of $\mathrm{CO}_{2}$ per tree $(\mathrm{r}=0.235)$. However, the result of this study was similar to the results of research conducted by Lailati (2013) which stated there is no strong relationship between observed parameters and $\mathrm{CO}_{2}$ absorption.

In conclusion, the result of carbohydrate mass is directly proportional to the carbon dioxide absorption per leaf per hour. The highest absorption capacity of carbon dioxide per leaf per hour was found in T. catappa $(0.511$ $\mathrm{g} /$ leaf/hour) and the lowest in $C$. inophyllum $(0.056$ $\mathrm{g} /$ leaf/hour). In this study, plants with the highest to the lowest carbon dioxide absorption capacity, in sequence was found in $P$. indicus, T. catappa, M. elengi, S. mahagoni, $F$. decipiens, B. asiatica, and $C$. inophyllum. The results of linear regression analysis and correlation test indicated that there is no strong relationship between parameters and carbon dioxide absorption per leaf blade and per tree, also had no significant.

\section{REFERENCES}

Ardiansyah. 2009. Daya rosot karbon dioksida oleh beberapa jenis tanaman hutan kota di Kampus IPB Darmaga. [Hon. Thesis] Departemen Konservasi Sumber Daya Hutan Dan Ekowisata, Fakultas Kehutanan, IPB, Bogor. [Indonesian]

Benfey PN. 2016. Vascular Plant Structure, Growth, and Development. Soil And Plant Nutrition. Campbell Biology. 11th ed. Pearson Higher Education. New York.

Cahyaningrum ST, Hartoko A, Suryanti. 2014. Biomassa karbon mangrove pada kawasan mangrove Pulau Kemujan Taman Nasional Karimunjawa. Diponegoro Jurnal of Maquares (Manag Aquat Resour) 3(3): 34-42. [Indonesian]

Carvajal M. 2016. Investigation into $\mathrm{CO}_{2}$ absorption of the most representative agricultural crops of the region of Murcia. www.lessCO2.es.

Dahlan EN. 2008. Jumlah emisi gas $\mathrm{CO}_{2}$ dan pemilihan jenis tanaman berdaya rosot sangat tinggi: studi kasus di Kota Bogor. Jurnal Media Konservasi 13(2): 85-89. [Indonesian]

Fitter AH, Hay RKM. 2001. Environmental Physiology of Plants. 3rd ed. Academic Press, London.

Gratimah GRD. 2009. Analisis kebutuhan hutan kota sebagai penyerap gas $\mathrm{CO}_{2}$ antropogenik di pusat Kota Medan. [Thesis] FMIPA Universitas Sumatera Utara. [Indonesian]

Heldt HW. 2005. Plant Biochemistry. 3rd ed. Elsevier, New York. [Indonesia]

Kerstetter RA, Poethig RS. 1998. The specification of leaf identity during shoot development. Ann Rev Cell Develop Biol 14: 373-398.

Lailati M. 2013. Kemampuan rosot karbon dioksida 15 jenis tanaman koleksi di Kebun Raya Bogor. Jurnal Widyariset 16 (2): 277-286. [Indonesian]

Lee EY, Kang MS, Kim JK. 2014. The $\mathrm{CO}_{2}$ reduction potential calculation through the urban park construction. KIEAE J 14(2): 87 98.

Leman AM, Shamsuri MMS, Hariri A, Kadir AA, Idris AF, Afandi A. 2017. Correlation between plant physiology and $\mathrm{CO}_{2}$ removable. AIP Conf Proc 1885: 020009. DOI: 10.1063/1.5002203.

Lugina M, Ginoga KL, Wibowo A, Bainnaura A, Partiani T. 2011. Prosedur Operasi Standar (SOP) untuk Pengukuran Stok Karbon di Kawasan Konservasi. Pusat Penelitian dan Pengembangan Perubahan Iklim dan Kebijakan. Indonesia. [Indonesian]

McPherson E, Gregory and Simpson. James R. 1999. Carbon Dioxide Reduction: Through Urban Forestry. United States Department of Agriculture, Albany, CA.

Misni A, Jamaluddin S, Kamaruddin SM. 2015. Carbon sequestration through urban green reserve and open space. J Malaysian Institute of Planners 8: 101-122.

Nowak DJ, Greenfield EJ, Hoehn RE, Lapoint E. 2013. Carbon storage and sequestration by trees in urban and community areas of the United States. J Environ Pollut 178: 229-236.

Oviantari MV, Gunamantha IM, Ristiati Ni P, Santiasa IMPA, Astariani PPY. 2018. Carbon sequestration by above-ground biomass in urban green space in Singaraja City. Intl Conf Clim Change. DOI: $10.1088 / 1755$.

Pane MS, Yoza D, Sulaeman R. 2016. Potensi serapan karbon dioksida $\left(\mathrm{CO}_{2}\right)$ pada pohon peneduh di Jalan Soekarno Hatta Kota Pekan Baru. Jom Faperta UR 3 (2):-. [Indonesian]

Pérez-Pérez JM, Serrano-Cartagena J, Micol JL. 2002. Genetic analysis of natural variations in the architecture of Arabidopsis thaliana vegetative leaves. Genetics 162: 893-915

Purba E, Khairunisa AC. 2012. Kajian awal laju reaksi fotosintesis untuk penyerapan gas $\mathrm{CO}_{2}$ menggunakan mikroalga Tetraselmis chuii. Jurnal Rekayasa Proses 6 (1):-. [Indonesian]

Purwaningsih S. 2007. Kemampuan serapan karbon dioksida pada tanaman hutan kota di Kebun Raya Bogor. [Hpn. Thesis] Departemen 
Konservasi Sumber Daya Hutan dan Ekowisata, Fakultas Kehutanan, IPB, Bogor. [Indonesian]

Sadasivam S, Manickam A. 2005. Biochemical Methods. Revised Second Edition. New Age International Publishers, New Delhi.

Sari MB, Yulkifli, Kamus Z. 2015. Sistem pengukuran intensitas dan durasi penyinaran matahari Realtime PC berbasis LDR dan moto stepper. Jurnal Otomasi, Kontrol \& Instrumentasi 7 (1): $37 .$. [Indonesian]

Sinambela TSR. 2006. Kemampuan Serapan Karbon Dioksida 5 (Lima) Jenis Tanaman Hutan Kota. [Hon. Thesis]. Departemen Konservas
Sumber Daya Hutan dan Ekowisata, Fakultas Kehutanan, IPB, Bogor [Indonesian]

Sitompul SM, Guritno B. 1995. Analisis Pertumbuhan Tanaman. Gajah Mada Press, Yogyakarta. [Indonesian]

Taiz L, Zeiger E. 2003. Plant Physiology. Third Edition. Annals of Botany Company, Sinauer Associates Publisher, New York.

USGS 2008. Carbon sequestration to mitigate climate change. https://pubs.usgs.gov/fs/2008/3097/pdf/CarbonFS.pdf. [12 January 2017].

Ziska LH, Dukes JS. 2011. Weed Biology and Climate Change. Blackwell Publishing, USA. 